\title{
UN, NGOs and Refugees, Church World Service Lancaster and United Nations’ 10 Point Plan
}

\author{
Junhao Zhang* \\ Lancaster Country Day School, Pennsylvania 17603, USA \\ *Corresponding Author email: 1206909257@qq.com
}

Keywords: United Nations; NGOs; Church World Service; 10 Point Plan; Refugees

\begin{abstract}
This paper elaborates if NGOs comply or not to United Nations' 10 Point Plan for refugees. With a case study, this paper investigates how the NGOs "Church World Service Lancaster" deals with the policy of world-spread refugees. Moreover, this paper takes semi-structured interviews and open-ended surveys with Church World Service Lancaster and a group of refugees in America from Nepal, Democratic Republic of the Congo, and Syria. The research shows that "Church World Service Lancaster” partially follows the UN 10 Point Plan.
\end{abstract}

\section{Introduction}

Refugee Crisis is actually happening, and it's an issue that affects most of the countries today, including America [1]. According to Maha Hilal this year we reached a record number of 65.3 million of forcibly displaced people [2]. In this article I want to analyze how and if NGOs apply UN refugee guidelines [3]. In order to do so, I will conduct a case study, with a branch of a Christian NGO (Church World Service) in Lancaster, Penn [4-6]. Through interviewing refugees and NGO officers in semi-structured questionnaires, I will assess the level of knowledge of UN policies from refugees and officers [7]. United Nations has multiple guidelines toward refugee under the UNHCR (United Nation Agency for Refugee) [8]. In this article, I will focus on the "Refugee Protection and Mixed Migration: The10-point plan in action".

\section{Data Reporting}

Selectively, two main data included in the article are podcasts and interview concluded by officers and staffs from Church World Service Lancaster. The podcasts will lay out real life from refugee themselves. The face to face interview with the director for Church World Service Lancaster Christine Bear and Omar is semi-structured. It provides data information from the point of view of the NGO about three crucial parts of document mentioned above (Cooperation among key partners, Reception arrangements and Solutions for refugees)

Another important material direct from Church World Service is the information from interview. Surprisingly I got a chance to meet the person named Omar from CWS Lancaster, he was a case manager and also a refugee from Somalia-the protagonist from podcast episode 6. Here's his message as both being a staff in CWS Lancaster and a refugee.

\subsection{Interview: For Staff: Omar Mohammad}

This interview was adopted on December 5th 2017 with omar Mohammad. Omar was a refugee before he started his career as a case manager in CWS. This can be viewed as a successful case for refugee resettlement in Lancaster. The motivation he did this was because of his former refugee identity and so he wished to assist more people like him to make his life more meaningful. Omar played an important role as a case manager by having interviews with others (refugees) who would potentially settle in lancaster. Specifically they get the information or documents of refugees from the UN, but they will count on local government once get settled in the US:They are helped by a 
particular manager from CWS to rent houses, receiving 92500\$ from government for each individual and ensuring their job niche in the city. When asking whether he's aware of the relationship between the policies of CWS and those of United Nations, Omar asserted that he barely had contact as a staff with UN, so that we could summarize that there isn't much of contact between this two organizations.

Although Church World Service is Christian based, according to Omar, Religion plays no role whatsoever in accepting and receiving refugees from different countries or cultural backgrounds. Moreover he could not name any of international organization worked along with CWS. Rather, he could point out a few local organizations contained similar traits to CWS.

Omar also feels that the the refugee program from CWS indeed help to integrate refugees to Lancaster community.

\subsection{Interview: For Refugee}

This interview was adopted on December 5th 2017. From Somalia, Omar Mohammad arrived in Lancaster US 7 years ago on the account of the war in his mother country. Living in the UN refugee camp for few years and having UN's assistance with all documents needed, eventually he landed on the territory of US. Surprised by the condition in US: everything was not free for refugees, Omar's high expectation toward this country was vanished, but CWS worked well to make him feel at home. When asking about his future plan of whether staying in the US or going back to Somalia, His answer was: "No one would like to leave their country and became a refugee." In Lancaster county, as mentioned before, Omar did have a long-term job and it was apparently sufficient to support family daily consumption.

With respect ot his integration in the county, overall Omar faced challenges: culture, food, language, manner, etc when he just arrived, particularly because lots of but not every people were friendly in the wake of his refugee identity, but gradually he overcame the situation and thought that this was still a wonderful community.

\section{Data Analysis}

In this section I will analyze the answers collected in the field research by connecting with 3 aspects of the "UN 10 Point Plan": Cooperation Among Key Partners, Reception arrangements and Solutions for Refugees.

\subsection{Data Analysis - Staff}

Cooperation among Key Partners: From what has been learnt from the staffs, it is clear that the cooperation works well before settling in the US. For instance, both Omar and Christine provide us information about cooperation with the UN before settling. They also confirm that, after refugees are settled, the refugees count more on local government and other NGOs than on the UN. So there are two points between Church World Service and United Nations that still need to be enhanced: transnational/international initiatives and information sharing at global level.

Reception arrangement: It seems that reception arrangements for refugees works well along with UN 10 point plan. What's more important is that though Church World Service is Christian based, refugees from every religion will be accepted and treated equally by this organization.

\subsection{Data Analysis - Refugees}

From the perspective of refugees, there are lots of cooperation between the UN and CWS. In all cases, UN was responsible for connecting refugees and CWS by setting up every single document (to validate and prove their identities) that is needed. Nevertheless, once refugees are settled in the US, the cooperation seems becoming vague, since the refugees cannot recall further contacts with the UN after being received by CWS Lancaster.

As for reception arrangements, material support for refugee is well done, instead the mental support still needs to be improved due to the harsh condition when facing different cultural challenges. For instances, Omar was somehow differentiated by some local citizens because of his refugee 
identity. The Burmese couple was trying to adjust themselves and they cried for a whole year.

It is reasonable to admit that the CWS is successfully in implementing the progressive approach to solutions with a focus on only the three traditional durable solutions, voluntary repatriation, local integration and resettlement. Although, it is not clear by the answers I received if CWS is working in the scope of a more comprehensive approach to seeking solutions through different pathways such as those used to facilitate international mobility for education, work and family reunion.

\section{Conclusion}

Although the analysis relies on two interviews and three podcasts only, we can draw similar conclusions from them. We can conclude that most of the cooperation between the UN and the CWS happens before refugee families ares settled in Lancaster. After they are settled, CWS tends to rely only on local authorities. On one hand, this shows a very good integration in local and regional levels, which is one of the prescribed advices on the 10 point plan, but on the other hand this is an obstacle for sharing lessons learnt in a global level and makes settlement feedback for the UN harder.

Another conclusion we can draw from our research is that reception arrangements tend to follow the protocol established by the 10 point plan. Most of the cooperation between UN and NGOs in this case happen in the pre-settlement stage, and our research has shown that the cooperation in this stage is very useful. Another aspect has been shown in this article is that religion does not play a role although CWS is a Christian based NGO, so that means that refugees from all religions are embraced and settled regardless of their faith or lack of, and that is a very positive aspect of this NGO.

\section{References}

[1] Gatrell P. The world-wide web of humanitarianism: NGOs and population displacement in the third quarter of the twentieth century. European Review of History Revue Européenne Dhistoire, 2016(1-2):1-15.

[2] Christopher J. Orr, Kathleen C. Williams, Laurent K L, et al. Trying hard to adapt to a chaotic world: How complex challenges overwhelmed best intentions. Journal of Great Lakes Research, 2015, 41:139-149.

[3] Kalir B. The Jewish State of Anxiety: Between Moral Obligation and Fearism in the Treatment of African Asylum Seekers in Israel. Journal of Ethnic \& Migration Studies, 2015, 41(4):580-598.

[4] Aiken S R, Leigh C H. DAMS AND INDIGENOUS PEOPLES IN MALAYSIA: DEVELOPMENT, DISPLACEMENT AND RESETTLEMENT. Geografiska Annaler, 2015, 97(1):69-93.

[5] Culbertson, et al. Rethinking Coordination of Services to Refugees in Urban Areas: Managing the Crisis in Jordan and Lebanon. Journal of Software, 2016, 21(2):359-372.

[6] Hos R. Education in Emergencies: Case of a Community School for Syrian Refugees. European Journal of Educational Research, 2016, 5(2):53-60.

[7] Chomat A M, Solomons N W, Koski K G, et al. Quantitative Methodologies Reveal a Diversity of Nutrition, Infection/Illness, and Psychosocial Stressors During Pregnancy and Lactation in Rural Mam-Mayan Mother-Infant Dyads from the Western Highlands of Guatemala. Food \& Nutrition Bulletin, 2015, 36(4):1079-1090.

[8] South A, Jolliffe K. Forced Migration: Typology and Local Agency in Southeast Myanmar. Contemporary Southeast Asia, 2015, 37(2):211-241. 